\title{
ROMSKI MODEL SPRAWIEDLIWOŚCI NAPRAWCZEJ
}

Rodzimi przedstawiciele ruchu sprawiedliwości naprawczej, aby zobrazować preferowany model rozwiązywania konfliktów o podłożu prawnokarnym, chętnie sięgają do wzorów dla współczesnych Polaków bardzo egzotycznych bądź odległych w czasie. Przykładowo Monika Płatek powołuje się na zwyczaje nowozelandzkich Maorysów ${ }^{1}$, a Wojciech Zalewski także na tradycje hebrajskie $^{2}$, islamskie ${ }^{3}$, japońskie ${ }^{4}$, południowoafrykańskie ${ }^{5}$ oraz północnoamerykańskie (Indianie Nawaho ${ }^{6}$, Indianie Dene, Inuici ${ }^{7}$ ). Z kolei Anna Rosner poszukuje wzorów restorative justice ${ }^{8}$ wprawdzie w Polsce, ale w tej szlacheckiej, a więc już nieistniejącej ${ }^{9}$. Studiując obyczajowość polskich Romów, odkryłam z niemałym zdziwieniem, że żyją wśród nas ludzie, dla których tradycyjny sposób rozwiązywania sporów wciąż jest tym pierwszym i podstawowym, a oficjalny wymiar sprawiedliwości wydaje się całkiem zbędny. Sądzę, że warto przyjrzeć się bliżej tak zwanym sądom cygańskim, ich organizacji i znaczeniu. Być może w samym sercu współczesnej Europy, także w Polsce, znaleźć można formę realizacji idei sprawiedliwości, naprawczej, i to wciąż żywa.

Trudno omawiać procedurę karną bez szczątkowej chociaż znajomości prawa karnego materialnego. Podobnie jest z ,,sądownictwem” romskim. Opiera się ono na tradycjach, zwyczajach i moralności Romów. Dlatego zacznę od naszkicowania historii i obyczajowości Cyganów w Polsce ${ }^{10}$.

Grupa, która nazywamy dziś Romami, najprawdopodobniej wywędrowała z Indii około XI w. n.e. Poprzez Azję Mniejszą dotarła w XII w. na Półwysep Bałkański i na stałe zagościła w Europie ${ }^{11}$. Pierwsi Cyganie przybyli do Polski z Południa i zaczęli osiedlać się na Podkarpaciu. Już około 1500 r.,

${ }^{1}$ M. Płatek za: J. Consedinem, Wstẹp I, w: M. Płatek i M. Fajst (red.), Sprawiedliwość naprawcza. Idea. Teoria. Praktyka, Warszawa 2005, s. 9-11.

${ }^{2}$ W. Zalewski, Sprawiedliwość naprawcza. Poczatek ewolucji polskiego prawa karnego?, Gdańsk 2006, s. 95-96.

${ }^{3}$ Ibidem, s. 97-98.

4 Ibidem, s. 98.

5 Ibidem, s. 96.

${ }^{6}$ Ibidem, s. 195-197.

7 Ibidem, s. 96-97.

${ }^{8}$ Pojęcia „sprawiedliwość naprawcza” i „restorative justice” stosuję zamiennie.

${ }^{9}$ A. Rosner, Tradycja staropolskiego sadownictwa polubownego - próba zarysowania problemu, w: M. Płatek i M. Fajst (red.), op. cit., s. 37-58.

${ }^{10}$ Opieram się na własnych ustaleniach poczynionych w pracy dyplomowej pt. Prawo a kultura $w$ kontekście obyczajowości polskich Romów, napisanej pod kierunkiem dr. J. Pluty na Uniwersytecie Pedagogicznym im. KEN w Krakowie, 2010 r.

11 A. Bartosz, Nie bój się Cygana/Na dara Romestar, Sejny 2004, s. 19 i n. 
w wyniku rygorystycznych ustaw banicyjnych kolejna fala migracji napłynęła z Niemiec ${ }^{12}$. To właśnie Cyganie przybyli z Zachodu do dziś nazywaja siebie Polska Roma ${ }^{13}$. Tak zwana druga migracja Cyganów do Polski nastapiła w połowie XIX w. i obejmowała głównie grupy Kelderari/Kełderasze/Kalderasze (Kotlarze) z Rumunii i Lovari/Lowarzy (Koniarze) z Siedmiogrodu ${ }^{14}$. Ostatnia znacząca fala migracji romskiej miała miejsce w latach 90 . XX w., po obaleniu reżimu Ceauşescu w Rumunii. Ta grupa rumuńskich Romów pojawiła się w Polsce w celach zarobkowych i w większości tylko na pobyt tymczasowy, ale część z nich została na dłużej ${ }^{15}$. Cyganie są zatem częścią polskiego społeczeństwa już od co najmniej sześciu wieków i choć nigdy nie zasymilowali się jako grupa, to współuczestniczyli w losach polskiego narodu. Szczególnie bolesną kartą wspólnej historii są lata II wojny światowej. W wyniku nazistowskich zbrodni nakierowanych na eksterminację Cyganów, według różnych szacunków, zginęło nawet 50\% populacji europejskich Romów; w Polsce odsetek ten był wyraźnie wyższy ${ }^{16}$.

Obecnie terytorium Polski zamieszkuja przedstawiciele czterech głównych grup romskich: Cyganie Karpaccy (Bergitka Roma), Polska Roma, Kalderasze i Lowarzy. Ustawa z 6 stycznia 2005 r. o mniejszościach narodowych i etnicznych oraz o języku regionalnym ${ }^{17}$ wymienia 13 obecnych w Polsce mniejszości narodowych i etnicznych ${ }^{18}$, wśród tych ostatnich - Romów. W narodowym spisie powszechnym przeprowadzonym w 2002 r. 12731 osób zadeklarowało przynależność do mniejszości romskiej (najwięcej: małopolskie - 1678, dolnośląskie 1319, mazowieckie - 1291, ślaskie - 1189) ${ }^{19}$. Z kolei w najnowszym Narodowym Spisie Powszechnym Ludności i Mieszkań 2011 romską identyfikację narodowo-etniczną wskazało około 16 tys. osób ${ }^{20}$.

Natomiast szacunki przeprowadzone w ramach przygotowań do Programu na rzecz społeczności romskiej w Polsce, stworzonego przez MSWiA w 2003 r., wykazały, iż Polskę zamieszkuje grupa około 20750 Romów (najwięcej: małopolskie -3500 , dolnośląskie -2500 , śląskie -2300 , mazowieckie -1600$)^{21}$. Cyganie Karpaccy osiedli już wieki temu i tradycje wędrowne są im obce bądź dawno zapomniane. To odróżnia tę grupę od pozostałych i generuje różnice obyczajowe, rodzi też niechęć i lekceważenie Bergitka Roma ze strony dawnych koczowników ${ }^{22}$. Trudno więc mówić o wspólnych dla wszystkich Romów normach i wartościach obyczajowych. To co dla jednych jest tylko zapomnianym

${ }^{12}$ L. Mróz, Cyganie, Warszawa 1971, s. 179.

13 A. Bartosz, op. cit., s. 96.

14 Ibidem, s. 97.

15 P. Lechowski, Migracje Romów rumuńskich, w: A. Caban i G. Kondrasiuk (red.), Romowie. Przewodnik. Historia i kultura, Radom 2009, s. 29-30.

16 A. Bartosz, op. cit., s. 54-65.

17 Dz. U. 2005, Nr 17, poz. 14.1.

${ }^{18}$ Białoruską, czeską, litewską, niemiecką, ormiańską, rosyjską, słowacką, ukraińską, żydowską, karaimską, łemkowską, romską, tatarską.

19 A. J. Kowarska, O sqdach cygańskich, „Studia Romologica” 2008, nr 1, s. 79.

${ }^{20}$ Zob. http://www.stat.gov.pl/cps/rde/xbcr/gus/PUBL_lu_nps2011_wyniki_nsp2011_22032012.pdf, s. 18 .

${ }^{21}$ Zob. http://www2.mswia.gov.pl/ftp/pdf/aneks_nr1.rtf (19.06.2010).

${ }^{22}$ A. Bartosz, op. cit., s. 92-105. 
zwyczajem, dla innych jest regułą moralna, a nawet niepisanym prawem ${ }^{23}$. Dlatego też w swoim artykule skoncentruję się na podgrupach bardziej tradycyjnych: Polska Roma i Ketderasze. W opisie oprę się przede wszystkim na opracowaniach Adama Bartosza ${ }^{24}$ i Agnieszki J. Kowarskiej ${ }^{25}$, a uzupełniająco także na pracach Marcela Courthiadego ${ }^{26}$ oraz Eleny Marushiakovej i Vesselina Popova ${ }^{27}$.

Podstawowym pojęciem wiążącym się $\mathrm{z}$ obyczajowością Cyganów jest romanipen, czyli romskość, cygańskość, która zobowiązuje do przestrzegania pewnych reguł. Przeciwieństwem „,cygańskości” jest „niecygańskość”, obcość zwana gadzipen.

Wśród głównych zasad romanipen szczególnie widoczny dla zewnętrznego świata jest nakaz manifestowania cygańskości poprzez publiczne posługiwanie się językiem romani i podkreślanie swej odrębności. Ma to zespolić grupę i wymusić absolutną solidarność jednostki z rodzina, rodem, nacia. Wyrządzenie szkody Romowi przynosi wielką ujmę. Krzywdzenie gadzia, jeśli nie sprowadza problemów na społeczność cygańską, nie spotyka się zwykle z negatywną reakcja pobratymców. Donoszenie i rozwiązywanie wewnętrznych konfliktów z pomocą władz państwowych jest absolutnie hańbiące.

Zasadnicze znaczenie ma też patyv, czyli cześć, ale też gościna. Patywato rom, to mężczyzna gościnny, zasługujący na szacunek. Uczta jest dla Romów nie tylko okazją do wspólnego, obfitego posiłku i zabawy, to także moment, w którym bardzo silnie uwidacznia się społeczna pozycja Roma. Tylko niepozbawieni czci członkowie grupy moga pić z jednego kieliszka i jeść wspólnie. Człowiek zhańbiony (magerdo) je na osobności.

Czcigodna może być również kobieta. Patyvali romni, to kobieta godna szacunku, także dziewica. Kobiecie nie wypada samej wychodzić z domu, stąd Cyganki chodzą najczęściej grupami. Romni nie powinna odsłaniać ciała i kokietować mężczyzn. Kobieta, od kiedy zacznie miesiączkować, staje się rytualnie nieczysta. Szczególnie nieczysta jest podczas porodu. Kalające sa części ciała od pasa w dół, a także bielizna i obuwie. Mężczyzna nie tylko nie powinien dotykać nieczystych części ciała ponad potrzebę niezbędną do prokreacji, ale nawet nie może pozwolić na upranie swoich rzeczy wraz z bielizną żony. Kobieta może go skalać celowo, na przykład dotykając go swoim butem.

Jeżeli dziewczyna znajdzie się z chłopcem sam na sam, to w odbiorze grupy para staje się $\mathrm{w}$ zasadzie narzeczeństwem. Tradycyjnie małżeństwa zawierane są bardzo wcześnie, gdy chłopiec ma 15-16 lat, a dziewczyna - 13-14; bardzo ważne jest, by była jeszcze dziewica. $\mathrm{W}$ zamożnych rodzinach małżeństwa kojarzone są przez rodziców, a ojciec kawalera płaci znaczną sumę za pannę, co ma zapewnić jej szacunek nowej rodziny. Ślubu (mangavipen) udziela starszy, czyli człowiek cieszący się dużym autorytetem w społeczności. Starszy

${ }^{23}$ Romska kultura ma charakter agraficzny, więc słowo pisane pozbawione jest tej symbolicznej wagi, jaką przypisuje mu np. kultura tzw. Zachodu.

${ }^{24}$ A. Bartosz, op. cit., s. 170-197.

${ }^{25}$ A. J. Kowarska, op. cit., s. 79-119.

${ }^{26}$ M. Courthiade, O romskim sadzie obyczajowym, „Studia Romologica” 2008, nr 1, s. 13-31.

${ }^{27}$ E. Marushiakova, V. Popov, Sad cygański w Europie Wschodniej, ,Studia Romologica” 2008, nr 1, s. $33-76$. 
obwiązuje ręce młodych chustą i wypowiada uroczystą formułę. Rytuał odbywa się w obecności najbliższych. Czasem, gdy wiek młodych na to pozwala, ślub legalizuje się $\mathrm{w}$ kościele ${ }^{28}$. Nowożeńcy zamieszkuja zwykle $\mathrm{z}$ rodziną męża i wciąż nie sa uważani za całkiem dorosłych i samodzielnych. Dojrzałości biologicznej nie towarzyszy dojrzałość społeczna. Młoda mężatka pozostaje pod silną władzą teściowej. Dopiero wraz z przyjściem na świat kolejnych dzieci małżonkowie zyskują sobie szacunek i większą niezależność.

Rodzina ma dla Romów ogromne znaczenie. Zarówno dzieci, jak i osoby starsze sa otoczone troskliwą opieką. Nie zdarza się w zasadzie, aby romskie dziecko trafiało do przytułku, a stary Rom - do ośrodka opieki. Dzieci sa skarbem i, jak pisałam wyżej, przysparzają szacunku rodzicom. Natomiast starsi służą radą, dbają o zachowanie tradycji, rozstrzygają spory, piętnują złe postawy. Dla Cyganów ważniejszy niż wiek, jest etap życia - starą nazwą osobę, która doczekała się wnuków (często przed 40 rokiem życia). Autorytetem może być ten, kto dzięki życiowemu doświadczeniu zdobył mądrość i potrafi z niej korzystać. Mężczyźni podkreślaja swoją pozycję wyglądem - tuszą, droga odzieżą, kapeluszem i biżuterią. Dla kobiety starość jest chyba najbardziej pożądanym etapem życia, gdyż dopiero po menopauzie traci właściwości kalające, a dzięki życiowej postawie może zyskać powszechny szacunek i posłuch. Zasada starszeństwa (phuripen) nakazuje szczególnie uprzejme zachowanie w obecności starszych oraz stosowanie grzecznościowych zwrotów: $b i b i, k a k, d a j$ i $d a d$ (ciocia, wujek, matka, ojciec).

Pośród różnych pomniejszych zasad warto jeszcze wspomnieć o ćaćipen, czyli zasadzie prawdomówności. Kłamstwo jest dla Romów niezwykle haniebne, nie dotyczy to jednak relacji z gadziami. Oszukanie nie-Roma odbierane jest zwykle jak oznaka sprytu.

Centralną instytucja romanipen, zwłaszcza dla grupy Polska Roma, jest mageripen - system skalań, grożących za złamanie zasad rytualno-moralnych. Kalające jest nie samo naruszenie reguły, a dostrzeżenie tego faktu przez innego Roma. Skalanie musi zostać ogłoszone przez upoważnionych do tego starszych. Za szczególnie ciężkie przewinienia (do których należą sprawy tak zwane kryminalne: umyślne zabójstwa czy spowodowanie uszczerbku na zdrowiu, wielkie ujmy na honorze, ewidentna nielojalność wobec Romów czy skalania kobiece [dźuwlitko mageripen]) Śero Rom, zwany też cygańskim królem, nakłada tak zwane wielkie skalania (bare mageripena). Drobniejsze sprawy sa załatwiane przez Jonkaro (zastępcę Sero Roma) lub lokalnego starszego za pomocą małych skalań (tykne megaripena). Sankcją wynikającą ze skalania jest najczęściej ostracyzm społeczny o różnym stopniu nasilenia i okresie trwania, w skrajnych przypadkach - dożywotnia infamia sprowadzająca się do wykluczenia ze społeczności romskiej. Kara ta jest tym dotkliwsza, że Rom odcięty od rodziny skazany jest na funkcjonowanie w środowisku gadziów, od których dotąd wyraźnie się dystansował - trudna do przełamania podejrzliwość i niechęć towarzyszy tu obydwu stronom. Często stosowane są też pieniężne odszkodowania i różne formy zadośćuczynienia (na przykład zorganizowanie przyjęcia dla rodziny pokrzywdzonego). Romowie

${ }^{28}$ Romowie przyjmują zwykle wiarę ludności, wśród której żyją. W Polsce większość to chrześcijanie (katolicy, prawosławni, protestanci). Por. A. Bartosz, op. cit., s. 119-137. 
dopuszczaja pewne formy samosądu polegające na pobiciu winnego, jednak wbrew krążącym pogłoskom - nie odnotowano przypadków karania śmiercią. Brak tu jakiegoś precyzyjnie określonego katalogu sankcji, gdyż są one dobierane do indywidualnych przypadków.

Konsekwencje związane z nieprzestrzeganiem romanipen świadczą o tym, że przedstawione wyżej reguły są czymś więcej niż tylko zwyczajem. Stopień sformalizowania tego systemu każe uplasować go na granicy między regułami moralnymi a prawnymi, co tym bardziej skłania do poważniejszego traktowania tak zwanych sądów cygańskich. Dla uproszczenia przekazu, w opisie romskich instytucji będę posługiwać się terminologia zaczerpniętą z polskiego procesu karnego, ze świadomością, że analogia jest dość odległa i sprowadza się wyłącznie do zbliżonej roli tych instytucji w postępowaniu.

„Sąy” cygańskie ${ }^{29}$ powoływane są do rozstrzygania najpoważniejszych konfliktów między Romami. Przedmiotem obrad mogą stać się zarówno sprawy kryminalne, jak i spory o innym podłożu. U Polska Roma instytucja nazywana jest celo i wyraźnie przewodzi jej Śso Rom. Ketderasze zwołują kris, a rolę pierwszego wśród równych pełni Krisako Rom. Ze względu na niewielkie różnice pomiędzy celo a kris będę opisywała je łącznie, pamiętając jednak o odmiennej roli przewodniczącego. Przed powołaniem ,sądu” lokalny lider ${ }^{30}$ stara się zwykle pomóc w rozwiązaniu konfliktu w miejscu jego powstania, u Polska Roma - sięga zwykle po system skalań, aby napiętnować nieakceptowane zachowania. Jeżeli te swoiste mediacje nie przyniosą efektów i strony nie chca przyjąc proponowanego rozwiązania, nie poddaja się skalaniu, a grupa nadal jest podzielona, przedstawiciele rodów zbieraja się, aby upublicznić spór w ramach romskiej społeczności i wspólnie go przedyskutować, a następnie rozwiązać. Taka dwupoziomowa konstrukcja jest świadectwem funkcjonowania $\mathrm{w}$ środowisku romskim zasady subsydiarności - jednej z podstaw ustroju demokratycznego.

W skład „sądu” cygańskiego wchodza jedynie dojrzali i cieszący się autorytetem mężczyźni. Wybierani są przez starszych rodu ${ }^{31}$, z którego się wywodzą i który będą reprezentować w obradach. Liczba „sędziów” zależy od wagi i złożoności sprawy, zwykle jest nieparzysta i wynosi od 3 do 25, najczęściej 11-15. W niektórych grupach każda ze stron wyznacza równą liczbę sędziów, a na osobę nieparzystą muszą zgodzić się obydwie strony.

Choć przebiegowi spotkania towarzysza pewne utrwalone rytuały, to jego formalizm nie jest wielki. Społeczność zbiera się w miejscu neutralnym dla stron, często przy zastawionych stołach. W zgromadzeniu moga brać udział wyłącznie Romowie, choć zdarzały się wyjątki od tej zasady ${ }^{32}$. Poza wybranymi

\footnotetext{
${ }^{29}$ Poniższą charakterystykę opieram na wspomnianych już studiach A. J. Kowarskiej, M. Courthiadego oraz E. Marushiakovej i V. Popova.

${ }^{30}$ Dojrzała osoba ciesząca się powszechnym szacunkiem grupy, często dziedzicząca tę rolę po przodkach, zwykle mężczyzna, bywa, że kobieta - przykładem może być zmarła w 2001 r. Jonkari Leokadia Waszkowska znana jako bibi Mania (ciotka Mania), należąca do Polska Roma z Suwałk albo na mniejszą skalę - Izolda Kwiek, przewodząca Ketderaszom z Rudy Sląskiej.

${ }^{31}$ Ród (romskie: vicia), czyli kilka rodzin wywodzących się od wspólnego przodka. Por. A. Mirga, L. Mróz, Cyganie. Odmienność i nietolerancja, Warszawa 1994, s. 119.

${ }^{32}$ Głośna sprawa konfliktu w latach 2006-2007 pomiędzy dwoma Romami: Bogdanem Trojankiem i Romanem Chojnackim, opisana m.in. przez A. J. Kowarska, op. cit., s. 105-106.
} 
starszymi zapraszani są także wszyscy inni członkowie wspólnoty, z wyjątkiem małych dzieci. Siadają według starszeństwa, osobno mężczyźni, osobno kobiety. Szczególnie eksponowanymi członkami zebrania sa panny na wydaniu, gdyż celo tradycyjnie jest też okazją do kojarzenia małżeństw.

Podczas obrad wypowiadaja się głównie mężczyźni, zwłaszcza głowy rodzin. Poważane kobiety są proszone o głos w tak zwanych sprawach kobiecych, a więc gdy kobieta jest stroną bądź przyczyną konfliktu. Oczywiście kluczowe sa wypowiedzi stron, członków ich rodzin i świadków zdarzenia. Każdy, kto chce zabrać głos, ceremonialnie prosi o zgodę. Nie wypada przerywać sobie nawzajem. Przedmiotem dyskusji jest nie tylko główna przyczyna spotkania, ale też wiele wątków pobocznych, które mają dać „,sędziom” jak najpełniejszy obraz sytuacji i przypomnieć rozstrzygnięcia w innych podobnych sprawach. Problem nie może pozostać nierozwiązany, dlatego przy braku zgody co do stanu faktycznego Cyganie sięgają po instytucję przysięgi (sovtah). Krzywoprzysięzca sprowadza na siebie nieszczęścia objęte słowami przysięgi. Rytualny charakter sovtah $^{33}$ dodaje wiarygodności zeznaniom. Gdy Śero Rom potwierdzi prawidłowy przebieg przysięgi, pijąc z zeznającym z jednego kieliszka, jego słowa staja się podstawą rozstrzygnięcia.

Obrady trwaja tyle czasu, ile zgromadzenie potrzebuje na wypracowanie satysfakcjonującego rozwiązania. Podstawą rozstrzygnięcia są zasady romanipen. Celem nigdy nie jest samo wskazanie i ukaranie winnego, ale ochrona jedności wspólnoty, wygaszenie konfliktu w sposób jednogłośnie zaaprobowany. Choć ,wyrok” ogłaszany jest przez przewodniczącego (Śero Rom lub Krisako Rom), zawsze jest wypracowany wspólnie przez wszystkich starszych i wymaga akceptacji ze strony osób bezpośrednio zaangażowanych w konflikt, także „,skazanego". Powszechna akceptacja jest jedyna gwarancja wykonalności postanowienia. Z drugiej strony, ,wyrok" niewykonalny pozbawiłby szacunku jego autorów. Znalezienie satysfakcjonującego wszystkich rozwiązania leży więc w interesie całej społeczności. Co do zasady, postanowienie „sądu” romskiego jest ostateczne, bywa jednak, że na skutek ujawnienia nowych dowodów sprawa rozpatrywana jest ponownie przez liczniejszą grupę. Trzykrotne zwoływanie ,sądu” w tej samej sprawie jest już prawdziwą rzadkością i nie jest mile widziane, gdyż podważa autorytet „,sędziów”"

Postanowienie ,sądu” cygańskiego zwykle obejmuje pieniężne odszkodowanie lub inne formy zadośćuczynienia. Liderzy uwzględniaja finansowa sytuację osądzonego i staraja się zapewnić mu możliwość normalnego egzystowania mimo obciążeń związanych $\mathrm{z}$ odszkodowaniem. Takie rozwiązanie zapobiega marginalizacji „skazanych”. Realizacja postanowienia „,sądu” ma zagwarantować przywrócenie społecznej równowagi. Przynosi „,podsądnemu” oczyszczenie z ciążącej na nim hańby. „Sąd” romski stoi na straży nie tylko porządku, ale też jedności wspólnoty, zachowania jej tradycji i tożsamości.

\footnotetext{
${ }^{33}$ Wyróżnia się lekkie przysięgi (ze świecami) i ciężkie przysięgi (np. wygłaszane z trumny), towarzyszą im symbole religijne, często wygłaszane są na cmentarzu lub w kościele, zwykle nago (tylko w prześcieradle, by złe moce nie przeszły na odzież zamiast na krzywoprzysięzcę).

${ }^{34}$ E. Marushiakova, V. Popov, op. cit., s. 59.
} 
Procedura rozstrzygania konfliktów w środowisku romskim z pewnościa różni się od utrwalonych w Polsce wzorców postępowania karnego, ale czy równocześnie wkomponowuje się w koncepcję restorative justice? Aby odpowiedzieć na to pytanie, wypada przeanalizować pokrótce znane w literaturze zasady i modele sprawiedliwości naprawczej.

M. Płatek w skondensowanej formie przedstawia główne założenia i wyróżniki sprawiedliwości naprawczej. Zdaniem autorki, jej filary stanowią:

a) prawo ofiary do rekompensaty,

b) zobowiązanie sprawcy do odpowiedzialności i naprawienia wyrządzonej krzywdy,

c) uczestnictwo stron i społeczności lokalnej w procesie prowadzącym do restytucji przez sprawcę szkody wyrządzonej ofierze ${ }^{35}$.

Trudno zaprzeczyć twierdzeniu, że ,sądy” cygańskie w formie przedstawionej powyżej te kryteria spełniają. Wynagrodzenie szkód w sposób akceptowalny dla wszystkich zebranych jest wszak jednym z głównych celów „sądu”, a udział stron i członków romskiej wspólnoty jest tu nieodzowny.

Jeśli przyjrzymy się funkcjom przypisywanym sprawiedliwości naprawczej, to można odnieść wrażenie, że romski model jest wręcz stworzony do ich realizacji. M. Płatek wylicza (za L. Nader i E. Combs-Schilling) sześć takich funkcji. Sprawiedliwość naprawcza:

a) pozwala uniknąć dalszej eskalacji konfliktu,

b) umożliwia szybszy powrót sprawcy do społeczności,

c) zaspakaja potrzeby pokrzywdzonego przestępstwem,

d) przywraca znaczenie wartości w społeczności istotnych,

e) skutecznie uczy społeczeństwo obowiązujących norm i wartości,

f) dostarcza procedur postępowania w przypadku złamania obowiązujących regut $^{36}$.

Być może nie ma w tym nic niezwykłego czy odkrywczego; być może wszystkie pierwotne sposoby rozstrzygania konfliktów z założenia służyły przywróceniu społeczeństwu spójności i równowagi, a sprawiedliwość wyroku była tylko pochodną tych założeń. Niemniej jednak to właśnie te funkcje były przez pokolenia spychane na margines europejskiej procedury karnej i to ku nim skłaniają się współcześni reformatorzy. Warto więc szukać nowych wzorców.

Czy romski model jest istotnie nowy, inny od opisywanych już w literaturze? Przytaczanie szczegółowych charakterystyk znanych na świecie systemów restorative justice wydaje się tu niecelowe, zwłaszcza że doczekały się one już niejednej klasyfikacji. Najpraktyczniejszy jest chyba podział dokonany przez Paula McColda (przytoczony też przez W. Zalewskiego), którego podstawowym kryterium jest skład forum uczestniczącego w wypracowaniu rozwiązania. Opierając się na obserwacjach różnorodnych plemiennych metod rozwiązywania konfliktów P. McCold wyróżnia:

${ }^{35}$ M. Płatek, Teoria sprawiedliwości naprawczej, w: eadem, M. Fajst (red.), op. cit., s. 77.

${ }^{36}$ L. Nader, E. Combs-Schilling, Restitution in Cross-Cultural Perspectives, w: J. Hudson, B. Galaway, Restitution in Criminal Justice, Lexington, MA, 1977, s. 34-35, cyt. za: M. Płatek, Teoria..., s. 95 . 

a) mediacje,
b) konferencje,
c) koła.

W klasycznej mediacji, poza sprawcą i pokrzywdzonym, uczestniczy jedynie neutralny mediator, ułatwiający stronom osiągnięcie porozumienia. Podczas mediacji mogą być obecne inne osoby, na przykład krewni stron, ale jedynie w charakterze obserwatorów.

Modelem bardziej rozbudowanym, a zarazem skuteczniejszym w sprawach karnych, jest konferencja sprawiedliwości naprawczej. Obok osób bezpośrednio zainteresowanych uczestniczą w niej rodziny i społeczność lokalna, co niweluje, typową dla relacji ofiara-sprawca nierówność stron. Osoby wspierające i członkowie lokalnej wspólnoty są pełnoprawnymi uczestnikami dyskursu, moga proponować rozwiązania i występować w obronie norm społecznych. Konferencja ma oddziaływać wychowawczo nie tylko na sprawcę, ale też na członków wspólnoty, utrwalając uznawane wartości. Spotkanie prowadzi $\mathrm{z}$ reguły profesjonalista, będący moderatorem dyskusji.

Koła sprawiedliwości naprawczej (circles) są metodą najbardziej złożoną. Od konferencji różnią się tym, że spotkanie prowadzi lider (liderzy) wspólnoty cieszący się powszechnym autorytetem. Jego zadaniem jest przedstawienie poglądu na sytuację zgodnego z tradycyjnymi wartościami i zwyczajami. Nie narzuca rozwiązań, ale ukierunkowuje strony tak, aby postanowienia ugody były w pełni akceptowalne przez wspólnotę. W ramach takich kręgów także społeczność lokalna może być uznana za ofiarę i wysuwać żądania wobec sprawcy. Spotkania tego typu nie maja jednak charakteru konfrontacji, ich celem jest przywrócenie ładu społecznego ${ }^{37}$.

Za przejaw sprawiedliwości naprawczej można uznać również negocjacje, w których strony konfliktu osiagają kompromis bez pośrednictwa osoby trzeciej $^{38}$. Słusznie jednak zauważa M. Płatek, że założenia restorative justice w pełni realizuja jedynie konferencje (autorka nie wyróżnia kręgów jako osobnego modelu), które angażują wszystkie osoby zainteresowane rozwiązaniem sporu i przywróceniem ładu społecznego ${ }^{39}$.

Na pierwszy rzut oka to właśnie koła sprawiedliwości naprawczej najbliższe są romskiemu kris (celo). Zatem przyjrzyjmy się im bliżej. P. McCold omawia instytucję kręgów na przykładzie tradycji Indian Nawaho (USA), rdzennej społeczności Jukonu (Kanada) oraz plemienia Ojibwa z Hollow Water (Manitoba, Kanada ${ }^{40}$. Te trzy północnoamerykańskie modele różnią się od siebie w znaczący sposób. W opisach zwracają jednak uwagę dwie charakterystyczne kwestie: silny udział całej społeczności i brak neutralnego pośrednika. Wspólnota pełni rolę nie tylko widowni, czy gwaranta prawidłowego przebiegu procesu, ale pełnoprawnego uczestnika dyskursu. Każdy członek zgromadzenia może wpływać na ostateczne rozstrzygnięcie, wyrażając swoje zdanie.

${ }^{37}$ P. McCold, Restorative Justice Practice - The State of The Field, 1999, http://www.iirp. org/article_detail.php?article_id=NTA0 (29.03.2011).

38 M. Płatek, Wstęp I, s. 15-16.

${ }^{39}$ M. Płatek, Wstęp I, s. 19-20.

${ }^{40}$ P. McCold, op. cit. 
Znaczenie lidera $\mathrm{w}$ trzech opisywanych przez P. McColda typach kręgów kształtuje się już odmiennie. Wspólne jest to, że osoba przewodnicząca spotkaniu, w przeciwieństwie do mediatora czy moderatora konferencji, nie jest bezstronna. Nawajski naat'aanil, choć nie narzuca rozwiązań grupie, dzięki swojemu autorytetowi ma głos decydujący ${ }^{41}$. W jukońskim modelu sentencing circles (SC) opiekunów (keepers) może być dwóch. Wybierani są przez lokalną społeczność. Łączą oni role organizacyjne z obrzędowymi. Ich wpływ na rezultat dyskusji jest, jak się wydaje, mniejszy niż w wypadku Navajo justice ${ }^{42}$. Healing circles (HC) w Hollow Water ukształtowane sa w celu rozwiązywania takich długofalowych problemów, jak przemoc domowa czy przestępczość seksualna. Złożona struktura tych manitobańskich kręgów nie zakłada dominującej roli lokalnego lidera, ale też nie wymaga udziału osoby bezstronnej, przypominającej mediatora ${ }^{43}$.

Porównanie cygańskiego „,sądu” z trzema powyższymi modelami kręgów sprawiedliwości naprawczej unaocznia odmienną strukturę przewodnictwa. Niezależnie od tego, czy rozpatrujemy kris, czy celo, rozstrzygnięcie problemu należy do organu kolegialnego. Różnica tkwi tylko w roli Śro Rom i Krisako Rom, gdyż ten pierwszy - jak już wspominałam - ma głos decydujący, a drugi pełni raczej funkcje organizacyjno-porządkowe, jako primus inter pares. Silna pozycję ,,sądu” w zgromadzeniu romskiej wspólnoty porównać można z rola, jaka pełni naat'aanil w kręgach Indian Nawaho. Prawo decydowania o losach członków grupy jest im dane dzięki osobistym zasługom i szacunkowi, jakim cieszą się $\mathrm{W}$ społeczności. Prawo to znajduje się pod nieustanną kontrola zgromadzonych, a utrata zaufania pociąga za sobą pozbawienie wpływów. Ignorowanie woli większości wspólnoty nie wchodzi w grę. Kolegialny charakter „sądu” romskiego z pewnością obniża sprawność jego działania, ale też zapewnia bardziej wszechstronna analizę postanowien. Ostateczna decyzja cygańskiego „sądu” podejmowana jest dwu-, a nawet trzypoziomowo. Swoja wolę wyrażają najpierw strony, ich rodziny i inni przedstawiciele społeczności, w dyskusji docierają stanowiska, a następnie punkty wspólne wyłuskuje ,sąd”. U Polska Roma szczegółowe rozwiązania zależą od Sero Roma, ale i one uzyskać powinny akceptację celo i reszty wspólnoty.

Czy z podobieństwa romano kris i celo do opisywanych w literaturze kręgów rawiedliwości naprawczej można wyciągnąć jakieś wnioski? Myślę, że szczególnie interesująca może być obserwacja koegzystencji zaawansowanych modeli restorative justice $\mathrm{z}$ państwowym wymiarem sprawiedliwości. Zagadnienie to wymagałoby szeroko zakrojonych badań międzynarodowych. Warto jednak przytoczyć po raz kolejny przykład rdzennej ludności Jukonu. Model SC zakłada

${ }^{41}$ R. Yazzi, Navajo Peacemaking: Implications for Adjudication-Based Systems of Justice, „Contemporary Justice Review” 1, 1998, s. 123-124, omawiam za: P. McCold, op. cit.

${ }^{42}$ B. Stuart, Circle Sentencing in Yukon Territory, Canada: A Partnership of the Community and the Criminal Justice System, „International Journal of Comparative and Applied Criminal Justice” 20, 1996, nr 1 \& 2, s. 291-309, omawiam za: P. McCold, op. cit.

${ }^{43}$ J. Bushie, CHCH Reflections. In Ministry of the Solicitor General of Canada. The Four Circles of Hollow Water. Aboriginal Peoples Collection, http://www.publicsafety.gc.ca/res/cor/apc/apc-15-eng. aspx (29.03.2011). 
pełną współpracę społeczności lokalnej z oficjalnym sądownictwem. Nie dość, że w kręgu udział wziąć moga (poza stronami, lokalną społecznością i jej liderem/,liderami”), także policjant, prokurator, adwokat i sędzia, to jeszcze same spotkania odbywają się najczęściej w budynku sądu. Przedstawiciele organów wymiaru sprawiedliwości są świadkami i drugoplanowymi uczestnikami dyskusji na temat okoliczności przestępstwa, losów sprawcy i ofiary, zależności ich łączących, wpływu zdarzenia na wspólnotę. Na wstępie lider przedstawia uczestników spotkania i problem, który maja przedyskutować. Potem każdy członek społeczności może wypowiedzieć się czterokrotnie: raz, by przedstawić przyczyny swojej obecności na spotkaniu, drugi - by wyrazić ofierze przestępstwa swoje wsparcie, i po raz kolejny, aby wyjaśnić sprawcy, jakie konsekwencje przyniósł jego czyn, nie tylko dla pokrzywdzonego. Czwarta wypowiedź podsumowuje spotkanie, może zawierać propozycje rozstrzygnięcia sprawy. Koło rekomenduje sędziemu pożądane rozwiązanie problemu, a sędzia uzyskuje pełniejszy niż podczas zwykłej rozprawy obraz sytuacji, z jaką ma do czynienia. Wspólnie wypracowany pogląd staje się podstawą wyroku sformułowanego przez sąd w imieniu państwa ${ }^{44}$. Kanadyjskie rozwiązanie niweluje problem dualizmu odpowiedzialności i równocześnie zapewnia wszystkim zainteresowanym członkom wspólnoty poczucie przynależności i realnego wpływu na losy grupy.

Inspiracją może stać się też funkcjonowanie pierwszego formalnego „,sądu” romskiego w Rumunii ${ }^{45}$. Romska mniejszość w tym kraju jest znacznie liczniejsza niż w Polsce, oficjalnie bowiem liczy około 0,5 mln osób, i jej obyczajowość jest ważnym elementem kulturowego krajobrazu Rumunii. Nie od dziś rumuńskie sądy borykają się z tym problemem, a romanipen nierzadko ma pośredni wpływ na treść orzeczeń. Często rozstrzygnięcia „sądów” romskich spotykają się wręcz z cichą akceptacją władz państwowych ${ }^{46}$. Niedawno jednak (28 lutego $2011 \mathrm{r}$.) w Sibiu (w południowej Transylwanii) ustanowiony został oficjalny ,,sąd” romski, zwany w Rumunii staborem. Twórca jest 41-letni Dorin Cioaba, absolwent prawa i równocześnie syn samozwańczego króla romskiego Florina Cioaby. ,Sąd” składa się z jego założyciela - przewodniczącego i siedmiu innych mężczyzn - liderów poszczególnych rodzin romskich z okolicy. Zadaniem staboru jest pomoc w rozstrzyganiu w zgodzie z miejscowym obyczajem sporów powstałych pomiędzy członkami społeczności romskiej, zanim jeszcze konieczna będzie interwencja organów państwowego wymiaru sprawiedliwości. Dorin Cioaba dzięki swemu prawniczemu wykształceniu służy swym pobratymcom także poradą prawną w sytuacji, gdy kontakt z państwowymi instytucjami staje się nieuchronny. ,Sąd” w Sibiu pełni więc rolę ośrodka mediacji przedsądowej, który pomaga $\mathrm{w}$ uporaniu się $\mathrm{z}$ konfliktem na przedpolu możliwego przestępstwa i równocześnie jest rodzajem poradni prawnej dla Romów. Choć inicjatywa Dorina Cioby spotkała się z krytyką, także części Romów, to jednak

\footnotetext{
${ }^{44}$ P. McCold, op. cit.

${ }^{45}$ Notka prasowa z 1 marca 2011 r., http://www.balkaninsight.com/en/article/court-of-gypsiesholds-its-first-official-session-in-romania.

${ }^{46}$ M. Courthiade, op. cit., s. 27-28.
} 
wydaje się rozwiązaniem interesującym. Warto, jak sądzę, obserwować zarówno rozwój tej instytucji, jak i zmieniający się status romanipen w Rumunii.

Skoro w Kanadzie realna jest ścisła współpraca między tradycyjnym i państwowym modelem rozwiązywania spraw karnych, a w Rumunii romski stabor realizuje postać mediacji przedsądowej, to może i na gruncie polskiego prawa istnieje szansa na wykorzystanie romskiego modelu? Oczywiście sprawa nie jest prosta. Romowie są w Polsce ludnością napływową i stanowią zaledwie odsetek naszego społeczeństwa. Choć preferowana metoda rozstrzygania przez nich sporów wydaje się kusząca, to przecież romskie materialne prawo obyczajowe $\mathrm{w}$ wielu punktach kłóci się z polskimi rozwiązaniami. Razi też brak równoprawnej pozycji kobiet $\mathrm{w}$ procesach cygańskich. To budzi sprzeciw wobec sięgania do takich wzorów. Optymizmu nie rodzi też kamienista droga, która w polskim prawie karnym kroczy mediacja - mniej złożona od konferencji czy kręgów forma realizacji restorative justice. Trudno więc odpowiedzialnie postulować rozpowszechnienie kół sprawiedliwości naprawczej w Polsce i włączenie ich do struktury wymiaru sprawiedliwości. Wracając jednak do myśli ze wstępu niniejszego artykułu, skoro o sprawiedliwości naprawczej pisze się w kontekście tak egzotycznych dla nas kultur azjatyckich, afrykańskich czy amerykańskich, dlaczego nie sięgnąć też po model bliższy nam geograficznie i funkcjonujący w sporej części Europy? Wszędzie tam, gdzie żyją przedstawiciele romskiej mniejszości etnicznej ${ }^{47}$, odnaleźć można różne warianty „sądów” cygańskich. Nawet jeśli nie staną się one inspiracją dla reformatorów prawa, ich znajomość może przyczynić się do odnalezienia wspólnej płaszczyzny radzenia sobie z konfliktami. Romowie, jako mieszkańcy Polski, często polscy obywatele, podlegaja polskiemu prawu; prawu, które jest dla nich równie obce aksjologicznie, jak dla gadziów obyczajowość romska. Być może szersze wykorzystanie narzędzi abolicyjno-naprawczych stanie się krokiem w kierunku rozwiązania tego problemu.

mgr Dominika Lorek

Uniwersytet Ślaski w Katowicach

dominika.lorek@us.edu.pl

THE ROMANI MODEL OF RESTORATIVE JUSTICE

Summary

The methods of alternative dispute resolution (ADR) are still a novelty in Poland and they need to be improved. While seeking the patterns of implementation of the idea of restorative justice in criminal law, it may be noteworthy to refer to the customary Romani 'courts' that exist in modern Europe. In the paper, the Authoress outlines the history and customs of Polish Roma/Gypsy people, still little known to the wider society. An essential part of the paper is devoted to the description of the functioning of so-called Romani courts. The conformity of their assumptions with the conception of circle models of restorative justice through a demonstration of Romani model against the background of other models described in the literature is then analysed.

${ }^{47}$ Dotyczy to tylko części grup cygańskich, por. E. Marushiakova, V. Popov, op. cit., s. 38. 
